\title{
Diploid Potato Germplasm with Resistance to Dickeya solani
}

\author{
Renata Lebecka $^{1}$ (D) - Iwona Wasilewicz-Flis ${ }^{1} \cdot$ Dariusz Mańkowski $^{2}$
}

Received: 21 January 2020 / Accepted: 2 October 2020/ Published online: 24 October 2020

(C) The Author(s) 2020

\begin{abstract}
Potato growers suffer losses due to potato soft rot and blackleg caused by pectinolytic bacteria of different species. These bacteria cause yield loss during cultivation and storage, and can be transmitted to the next generations through seed tubers. The prevalence of Pectobacterium atrosepticum has decreased over the last 20 years in Europe in favour of Dickeya solani and P. carotovorum subsp. brasiliense. Twenty-six diploid interspecific Solanum hybrids, previously selected for tuber resistance to $P$. atrosepticum, were screened for resistance to a highly aggressive $D$. solani strain in terms of tuber and blackleg reaction. The bacterial strain used for inoculation was characterised by a relatively high optimal growth temperature in vitro, ranging from 33 to $35{ }^{\circ} \mathrm{C}$. Twenty-four diploid clones did not differ in terms of tuber reaction to inoculation with this strain of bacteria in comparison with the clone USA 249, which is the somatic hybrid of $S$. brevidens (+) S. tuberosum with proven resistance to Pectobacterium. Seventeen clones performed significantly better in terms of blackleg resistance than the resistant potato cultivar Glada. Eleven of the selected diploids produced unreduced gametes, which allows their use in improving the resistance of tetraploid potatoes to diseases caused by bacteria of both Pectobacterium and Dickeya.
\end{abstract}

Keywords Pectinolytic bacteria $\cdot$ Potato blackleg $\cdot$ Screening methods $\cdot$ Tuber softrot $\cdot$ Wild species of Solanum

Electronic supplementary material The online version of this article (https://doi.org/10.1007/s11540-02009482-w) contains supplementary material, which is available to authorized users.

Renata Lebecka

R.Lebecka@ihar.edu.pl

1 Department of Potato Genetics and Parental Lines, Plant Breeding and Acclimatization Institute National Research Institute, Platanowa 19, 05-831 Młochów, Poland

2 Department of Seed Science and Technology, Plant Breeding and Acclimatization Institute National Research Institute, Radzików, Poland 


\section{Introduction}

Two diseases of potato (Solanum tuberosum), namely, blackleg of the foliage and soft rot of the tubers, are caused by soft rot Enterobacteriaceae (SRE), which belong to the genera Pectobacterium and Dickeya. In the past, mostly P. atrosepticum, then $D$. dianthicola and $P$. wasabiae, were the causative agents of blackleg in Europe, but at present the importance of $D$. solani and increasingly $P$. brasiliense sp. nov. is growing (van der Wolf et al. 2017; Portier et al. 2019).

SRE are characterised as hemibiotrophs by having one or two phases of infection, the first of which is the biotrophic phase, during which bacteria live in a living tissue, and the second of which is the necrotrophic phase, which results from the degradation activity of extracellular enzymes produced by bacteria that kills host cells (Kraepiel and Barny 2016). Latent infection occurs when only the first phase of infection takes place, and in this way, bacteria are transferred in seed tubers from generation to generation.

The losses caused by this complex of bacterial species are due to both the downgrading of seed potato plantations and losses of potato yield in fields and during storage. Chemical control against SRE is not widely applied, and using healthy seed potatoes combined with highly hygienic measures is recommended. In general, the level of resistance in potato cultivars is medium to low. Sources of high resistance to $P$. atrosepticum were found in diploid interspecific hybrids of potato (ZimnochGuzowska et al. 1999). The first genetic studies on the resistance of potato to $P$. atrosepticum in a diploid unselected population revealed the complex, polygenic inheritance of the trait. Several putative quantitative trait loci for resistance of tubers and leaves have been identified on all 12 potato chromosomes. Moreover, the inheritances of tuber and leaf resistance to $P$. atrosepticum are largely independent (Zimnoch-Guzowska et al. 2000), which makes it necessary to test tubers and aboveground parts of plant separately for resistance to SRE.

Studies on potato resistance to $D$. solani were initiated after the findings that this bacterium is more aggressive than other pectinolytic bacteria towards potato and that plant infection is initiated by a smaller number of bacteria than that by other bacterial species (Toth et al. 2011; Czajkowski et al. 2013). Data on the susceptibility of potato cultivars to D. solani are scarce; however, some differences in susceptibility among cultivars have been observed under Israeli conditions, where the blackleg incidence in the field ranged from 2 to $30 \%$ (Tsror et al. 2009). All major potato cultivars in field tests in England were susceptible to $D$. dianthicola, with some differences in symptom severity (Toth et al. 2011). Lebecka and Michalak (2017) evaluated the tuber resistance to a highly aggressive strain of D. solani (IFB0099) in 11 potato cultivars (Bryza, Denar, Glada, Irys, Jelly, Mieszko, Owacja, Satina, Sonda, Tajfun and Vineta), out of which the most resistant cultivars were Mieszko, Tajfun and Sonda. Lebecka and Czarniak (2019) tested the resistance of tubers of ten potato cultivars, namely, Brooke, Glada, Hermes, Irys, Lady Claire, Lady Rosetta, Omega, Smith Comet, Verdi and VR 808, using for inoculation two aggressive isolates of $D$. solani and P. brasiliense sp. nov. They found that a significant influence of cultivar on the weight of rotten tissue was observed (Lady Rosetta and Brooke performed significantly better than Hermes, Lady Claire and VR808), and bacterial isolate P. brasiliense sp. nov. (Pcb3M16) had higher aggressiveness than $D$. solani (IFB0099). Furthermore, the interaction of cultivar and isolate significantly influenced the tuber rot (cultivar Verdi showed more rot 
after infection by $D$. solani than after infection by $P$. brasiliense sp. nov., in contrast to Lady Claire).

SRE display various mechanisms of virulence and six transport systems. Pectin cell wall-degrading enzymes (PCWDEs) and their isoforms, secreted into plants by the type II secretion system (T2SS) regulated by quorum sensing, are the most significant virulence factors (Toth et al. 2003; Toth and Birch 2005). These enzymes have different properties, including different optimal temperatures for production. The expression of resistance to bacteria in potato depends on environmental conditions, among which temperature is very important. SRE differ in their optimal growth temperature: the optimal range of temperatures for $P$. atrosepticum and $P$. carotovorum subsp. carotovorum is $24-27{ }^{\circ} \mathrm{C}$ and $28-34{ }^{\circ} \mathrm{C}$, respectively, while that for Dickeya spp. is 31-37 ${ }^{\circ} \mathrm{C}$ (Perombelon and Kelman 1980; Latour et al. 2007; du Raan et al. 2016).

An extreme level of resistance to highly virulent bacteria in potato under conditions favourable for disease development has not been found in potato cultivars. To control these diseases, integrated measures, including cultivation of potato cultivars less susceptible to bacteria, are important.

Diploid clones, interspecific hybrids of Solanum spp., were evaluated in two different assays: for soft rot resistance by wound inoculation of tubers, and for blackleg resistance by wound inoculation of plant stem, because these two traits are partly independent. In previous studies, diploid clones expressed the resistance to $P$. atrosepticum in tubers. However, the blackleg resistance in these diploid clones has never been evaluated, with the exception of clone DG 88-9, tested previously by Zimnoch-Guzowska et al. (1999).

Pollen fertility and large pollen grains of diploid clones were evaluated for determination of their ability to be a pollen parent in crosses with diploid or tetraploid potato clones.

The in vitro optimal growth temperature of a highly aggressive strain of $D$. solaniIFB0099 (syn. IPO2276) - was determined as differences in optimal growth temperature among SRE species/genera are known, and because some of the bacteria causing potato blackleg, from genus Dickeya, have been found as 'cold strains' (Pérombelon 2002).

\section{Materials and Methods}

\section{Bacteria}

The highly virulent strain IFB0099 of D. solani (syn. IPO2276), isolated in Poland in 2005 from a symptomatic potato plant (Sławiak et al. 2009; Golanowska et al. 2015), was obtained in 2012 from the Intercollegiate Faculty of Biotechnology of University of Gdansk and Medical University of Gdańsk, Poland. This strain was selected for our study because until the present study there was no other more aggressive strain in our collection of pectinolytic bacteria (on average five isolates of bacteria are isolated each year and tested for their degree of virulence). In addition, this strain is well characterised for virulence factors (Golanowska et al. 2018) and has been sequenced (GenBank CP024711.1). Cryopreserved bacteria were revived in agar lysogeny broth (Luria Bertani, L3152 SIGMA) and harvested after $24 \mathrm{~h}$ of incubation at $27^{\circ} \mathrm{C}$. The 
optical density of the suspension was adjusted to an absorbance of 0.1 or 1.0 at $600 \mathrm{~nm}$ using a Hitachi U-1900 spectrophotometer. These densities were equivalent to $10^{8}$ and $10^{9} \mathrm{CFU} \mathrm{ml} \mathrm{m}^{-1}$, respectively, according to the calibration curves.

\section{Plant Material}

Twenty-five out of the 26 diploid interspecific hybrids of Solanum (Table 1) were selected out of 394 diploid clones based on high resistance to P. atrosepticum (Lebecka et al. 2013; Online Resource 1). The complexity of the origin of these hybrids is exemplified by clone DG 92-272, as shown in Online Resource 2. Two potato cultivars of Solanum tuberosum L., namely, Irys and Glada, were used as standards. Their resistance to blackleg (BL) and soft rot (SR) was 2 and 3, respectively, for cv. Irys, and 7 and 5, respectively, for cv. Glada, on a 1-9 grade scale where 9 is the most resistant (Polish National List of Agricultural Plant Varieties (Charakterystyka Krajowego Rejestru Odmian Ziemniaka), Ed. XIX; Jadwisin 2016). The somatic hybrid of S. tuberosum (+) S. brevidens, USA 249 (obtained from the USDA/ARS, Madison, WI, USA), was used as a standard high-resistance material (Austin et al. 1988).

\section{The Optimal Temperature for In Vitro Growth of Dickeya solani Strain IFB0099}

Bacterial growth was tested in a lysogeny broth (Luria Bertani, L3152 SIGMA) in two separate trials. The first trial was conducted at temperatures of $28{ }^{\circ} \mathrm{C}, 30{ }^{\circ} \mathrm{C}, 32{ }^{\circ} \mathrm{C}$, $33{ }^{\circ} \mathrm{C}$ and $34^{\circ} \mathrm{C}$ and the second trial was conducted at temperatures of $34{ }^{\circ} \mathrm{C}, 35^{\circ} \mathrm{C}$, $36{ }^{\circ} \mathrm{C}$ and $37^{\circ} \mathrm{C}$. The trials were conducted in a Thermo Scientific MaxQ benchtop orbital shaker with a rotation frequency of $130 \mathrm{rpm}$. A total of $0.5 \mathrm{ml}$ of the bacterial suspension, obtained from LB agar plates grown for $24 \mathrm{~h}$ at $27^{\circ} \mathrm{C}$ and adjusted to an optical density (OD) equal to 0.17 (in the first trial) and 0.16 (in the second trial) at a wavelength of $600 \mathrm{~nm}$, was added to Erlenmeyer flasks with $20 \mathrm{ml}$ of LB medium. Each of the experiments was conducted with three technical replicates. Bacterial growth was measured with a spectrophotometer after 6 and 8.5 h. Data sets were analysed for each trial separately.

\section{Testing Soft Rot Resistance to D. solani}

Potato tubers were stored for at least 1 month after harvest in two successive growing seasons. They were sterilised by submergence in a $1 \%$ sodium hypochloride solution for $15 \mathrm{~min}$, washed in water and air-dried at room temperature for 1 day before inoculation. Freshly wounded potato tubers were inoculated with bacteria (Dees et al. 2017). On each of three different test dates, 10 tubers per genotype and 20 tubers per standard cultivar were wounded with a steel rod $10 \mathrm{~mm}$ long and $2 \mathrm{~mm}$ wide and inoculated with $10 \mu \mathrm{l}$ of bacterial suspension with an $\mathrm{OD}_{600}=0.1$. The hole was covered with Vaseline on a piece of parafilm. The tubers were placed in plastic boxes and sprayed with water, and the boxes were covered with a lid. After incubation at $26{ }^{\circ} \mathrm{C}$ for 3 days, the tubers were cut vertically through the injection points, and the symptoms were scored. Two components of disease development were measured: the disease incidence (DI) was expressed as the proportion of tubers with symptoms of rotting, and the disease severity (DS) was expressed as the average weight (g) of the 
Table 1 Laboratory screening for plant and tuber resistance to Dickeya solani of diploid interspecific hybrids of Solanum spp., one somatic hybrid of S. tuberosum (+) S. brevidens (USA 249) and two potato cultivars (Glada and Irys) with known resistance: testing of diploids for pollen viability and ability to produce unreduced gametes

\begin{tabular}{|c|c|c|c|c|c|c|c|c|c|c|}
\hline & \multirow[t]{2}{*}{ Genotype } & \multicolumn{3}{|l|}{ Soft $\operatorname{rot}^{\S}$} & \multicolumn{3}{|c|}{ Blackleg\# } & \multirow{2}{*}{$\begin{array}{l}\text { Pollen viability }{ }^{\dagger} \\
\%\end{array}$} & \multicolumn{2}{|c|}{ Maintenance } \\
\hline & & SR & DS & DI & $N$ & $\%$ & & & Accession & number \\
\hline 1. & DG 88-9 & $0.00 \mathrm{a}$ & $0.00 \mathrm{a}$ & 0.00 & 76 & 5.0 & $* *$ & $50+$ & 356033 & \\
\hline 2. & DG 00-270 & $0.04 \mathrm{a}$ & $0.36 \mathrm{a}$ & 0.10 & 78 & 3.8 & $* *$ & $50+$ & 406829 & Field \\
\hline 3. & DG 06-600 & $0.14 \mathrm{a}$ & $1.39 \mathrm{a}$ & 0.10 & 79 & 2.6 & $* *$ & 75 & & \\
\hline 4. & DG 06-1 & $0.19 \mathrm{a}$ & $2.76 \mathrm{ab}$ & 0.07 & 56 & 0.0 & $* * *$ & $80+$ & & Field \\
\hline 5. & DG 06-5 & $0.18 \mathrm{a}$ & $0.36 \mathrm{a}$ & 0.50 & 74 & 0.0 & $* * *$ & 30 & 401899 & \\
\hline 6. & DG 06-1150 & $0.28 \mathrm{a}$ & $0.64 \mathrm{a}$ & 0.43 & 47 & 1.7 & $* * *$ & 50 & & NA \\
\hline 7. & DG 00-519 & $0.30 \mathrm{a}$ & $0.60 \mathrm{a}$ & 0.50 & 50 & 0.0 & $* * *$ & $60+$ & & NA \\
\hline 8. & DG 94-668 & $0.35 \mathrm{ab}$ & $0.74 \mathrm{a}$ & 0.47 & 62 & 15.8 & $*$ & $90 \mathrm{~L}+$ & 356076 & \\
\hline 9. & DG 06-28 & $0.36 \mathrm{ab}$ & $0.97 \mathrm{a}$ & 0.37 & 79 & 6.3 & $*$ & $30 \mathrm{~L}$ & 401017 & \\
\hline 10 & USA 249 & $0.37 \mathrm{ab}$ & $0.86 \mathrm{a}$ & 0.43 & NT & & & & In vitro & Field \\
\hline 11. & DG 00-683 & $0.44 a b$ & $1.21 \mathrm{a}$ & 0.37 & 75 & 27.1 & NS & 50 & 401012 & Field \\
\hline 12. & DG 04-842 & $0.45 a b$ & $0.75 \mathrm{a}$ & 0.57 & 76 & 14.1 & * & $75+$ & 401898 & \\
\hline 13. & DG 06-542 & $0.49 \mathrm{ab}$ & $0.77 \mathrm{a}$ & 0.63 & 52 & 15.7 & NS & 70 & & Field \\
\hline 14. & DG 00-1017 & $0.52 a b$ & $1.42 \mathrm{a}$ & 0.73 & 26 & 9.0 & * & $50+$ & & NA \\
\hline 15. & DG 06-508 & $0.53 \mathrm{ab}$ & $0.98 \mathrm{a}$ & 0.53 & 73 & 24.5 & NS & $70 \mathrm{~L}$ & & Field \\
\hline 16. & DG 00-468 & $0.54 \mathrm{ab}$ & $0.90 \mathrm{a}$ & 0.60 & 76 & 13.8 & NS & 70 & & Field \\
\hline 17. & DG 00-908 & $0.58 \mathrm{ab}$ & $0.92 \mathrm{a}$ & 0.60 & NT & & & & & NA \\
\hline 18. & DG 94-90 & $0.68 \mathrm{ab}$ & $1.20 \mathrm{a}$ & 0.57 & 59 & 53.5 & NS & 50 & 365067 & \\
\hline 19. & DG 94-272 & $0.78 \mathrm{abc}$ & $1.55 \mathrm{a}$ & 0.50 & 51 & 14.4 & $*$ & 50 & & Field \\
\hline 20. & DG 06-1073 & $0.85 \mathrm{abc}$ & $1.35 \mathrm{a}$ & 0.63 & 67 & 11.7 & $*$ & 40 & & Field \\
\hline 21. & DG 00-349 & $0.91 \mathrm{abc}$ & $1.52 \mathrm{a}$ & 0.60 & 58 & 21.2 & NS & $80+$ & & Field \\
\hline 22 & DG 06-567 & $0.94 \mathrm{abc}$ & $1.22 \mathrm{a}$ & 0.77 & 74 & 12.6 & NS & $70+$ & & Field \\
\hline 23. & DG 00-525 & $1.10 \mathrm{abc}$ & $1.27 \mathrm{a}$ & 0.87 & 71 & 1.4 & $* * *$ & 80 & & Field \\
\hline 24. & DG 06-455 & $1.23 \mathrm{abc}$ & $1.31 \mathrm{a}$ & 0.93 & 69 & 3.8 & $* *$ & $50+$ & & Field \\
\hline 25. & DG 00-849 & $2.00 \mathrm{bc}$ & $2.07 \mathrm{a}$ & 0.97 & 63 & 3.1 & $* *$ & 80 & 401013 & \\
\hline 26. & DG 04-814 & $2.35 \mathrm{c}$ & $2.43 \mathrm{ab}$ & 0.97 & 68 & 7.7 & $*$ & $40+$ & & Field \\
\hline 27. & Cultivar Glada & $4.69 \mathrm{~d}$ & $4.94 \mathrm{~b}$ & 0.97 & 130 & 55.5 & & & & \\
\hline 28. & DG 08-305 & $4.81 \mathrm{~d}$ & $4.97 \mathrm{~b}$ & 0.97 & 73 & 18.1 & NS & 75 & 406830 & Field \\
\hline 29. & Cultivar Irys & $12.97 \mathrm{e}$ & $12.97 \mathrm{c}$ & 1.00 & 164 & 79.1 & NS & & & \\
\hline
\end{tabular}

$\S$ Mean values that were obtained in three independent experiments, 30 tubers per genotype, from two growing seasons; SR — soft rot parameter, mean weight of rotten tissue of all tested tubers; DS — disease severity, mean weight of rotten tissue of tubers with symptoms; DI- disease incidence, proportion of tubers with rot symptoms, in columns SR or DS numbers followed by the same letter are not significantly different at $P \leq 0.05$ according to Duncan's test; \# number of tested plants $(N)$ and the mean percentage of plants $(\%)$ with symptoms of blackleg after inoculation with the isolate of $D$. solani that were assayed in two independent experiments; *, ** and *** are the significance of differences between tested clone/cultivar and the standard potato cv. Glada at $P \leq 0.05,0.01$ and 0.001 , respectively, according to Dunnett's test; NS — non-significant differences; $\dagger \mathrm{L}-$ low pollen production; + - large pollen grains observed among pollen of normal size; $\$$ diploid clones with the accession numbers are available from the collection of breeding clones at the Plant Breeding and Acclimatization Institute - National Research Institute, as in vitro plants https://wyszukiwarka.ihar.edu.pl/en/search/extended?passport=true; Field — clones multiplied in the field; NT—not tested; $N A$-not available 
rotten tissue, but only for tubers with symptoms of rotting (Fig. 1). These two components were used to calculate an SR parameter, where the DS is multiplied by DI, showing the average of rot in all tested tubers per genotype.

\section{Testing Blackleg Resistance in Greenhouse-Grown Plants}

The method of testing blackleg resistance was described by Lebecka (2017). Tuber eye plugs were planted, and stems of 3-week-old greenhouse plants were inoculated $1 \mathrm{~cm}$ above the soil with toothpicks kept in a bacterial inoculum with an $\mathrm{OD}_{600}=1.0$. The plants were watered and covered with a PCV tunnel to maintain high humidity (Fig. 2). The mean temperatures in the first 7 days of the test were relatively high (under the tunnel), and equalled $23.2{ }^{\circ} \mathrm{C}(\mathrm{SD}=7.0)$ and $26.2{ }^{\circ} \mathrm{C}(\mathrm{SD}=7.5)$ on the first and the second date of the test. The percentage of plants with symptoms of infection, specifically, blackleg and/or wilting with leaf necrosis, was observed 2 to 3 weeks postinoculation. A total of 26 to 80 plants per diploid clone and 130 to 164 plants per standard cultivar (Glada and Irys) were tested with two biological replicates.

\section{Pollen Fertility Test by Lactophenol Acid Fuchsin}

Pollen collected from a few mature flowers from a few potato plants was stained with lactophenol acid fuchsin on a glass slide. Diploid clones with low pollen production are marked in Table 1. The percentage of stained pollen grains and the presence of large

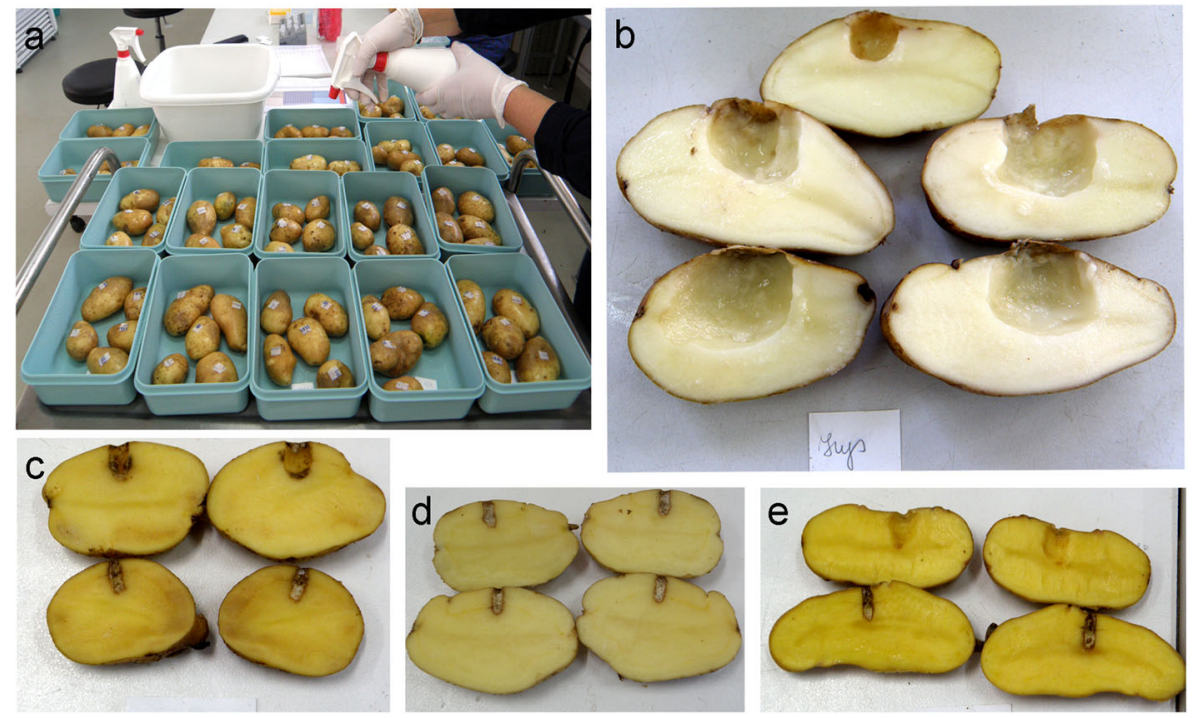

Fig. 1 Evaluation of tuber resistance to D. solani of potato. Disease severity (DS) was expressed as the average weight $(\mathrm{g})$ of the rotten tissue but only of tubers with symptoms of rotting, disease incidence (DI) as the proportion of tubers with symptoms of rotting, and soft rot (SR) parameter is the DS multiplied by DI. a Potato tubers, wound inoculated with bacteria and sprayed with water; $\mathbf{b}$ symptoms of infection in tubers of the potato cultivar Irys (macerated tissue removed); c symptoms in tubers of the diploid clone DG 06-5 (weak rotting or suberin formation); $\mathbf{d}$ symptoms in tubers of the diploid clone DG 88-9 (lack of rotting, suberin formation); e symptoms of the somatic hybrid USA 249 (standard highly resistant; weak rotting or suberin formation). Symptoms evaluated in tubers kept under humid conditions at $26^{\circ} \mathrm{C}$ for 3 days post-inoculation 

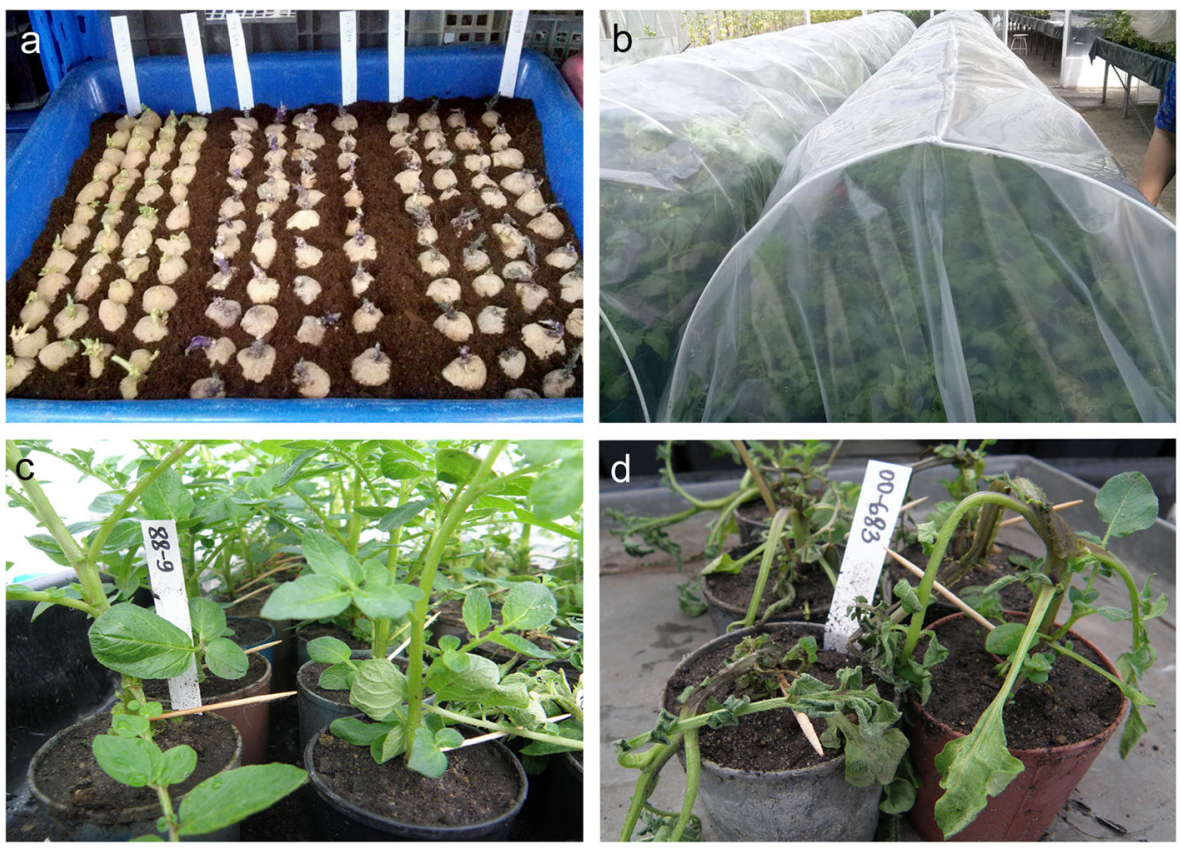

Fig. 2 Evaluation of plant resistance of potato to D. solani a sprouting in the light of eye plugs cut from potato tubers, b stem-inoculated plants watered and covered with a PCV tunnel to maintain high humidity, c symptomless plants of the diploid clone DG 88-9, d symptoms of blackleg in the diploid clone DG 00-683. Symptoms evaluated 2 to 3 weeks post-inoculation

pollen grains were evaluated using a light microscope. Pollen was observed in a few fields magnified to $\times 200$. The numbers of well-stained pollen grains without any deformation and their size were estimated for 100-200 grains (Wasilewicz-Flis 2011).

\section{Statistical Methods}

One- and two-way ANOVAs followed by Duncan's (for multiple comparisons) or Dunnett's (for comparing all treatments with a control) tests were used to evaluate the effects of the examined factors. When the assumptions of ANOVA were not met, a Kruskal-Wallis test (non-parametric) and multiple Kruskal-Wallis test for multiple comparisons were applied. For the percentage data, an angular transformation was used before analysis. All statistical analyses were performed using Statistica 13.3 software (Tibco Inc. 2017).

\section{Results and Discussion}

\section{The Optimal Temperature for In Vitro Growth of Strain IFB0099}

The optimal temperature for in vitro growth of various $D$. solani isolates investigated by du Raan and others (2016) ranged from 23 to $41^{\circ} \mathrm{C}$. This range was wide; therefore, we evaluated the optimal temperature for in vitro growth of the D. solani strain 
IFB0099. The multiplication of this strain was the highest in the range from 33 to $35{ }^{\circ} \mathrm{C}$ (Fig. 3). Temperature is the most important factor influencing both aggressiveness of bacteria and the resistance of potato tubers. In our previous study (Lebecka et al. 2018), the size of symptoms of infection in potato tubers caused by three different isolates of D. solani, namely, 748-2-2-12, IFB0458 and IFB0099, increased with temperature in the range of 18 to $30{ }^{\circ} \mathrm{C}$. The greatest differences in rotting of tubers among potato cultivars were observed at higher temperatures $\left(26-30{ }^{\circ} \mathrm{C}\right)$, while differences in the number of successfully infected tubers between medium-resistant and susceptible cultivars were observed at lower temperatures $\left(20-24{ }^{\circ} \mathrm{C}\right)$. Although the optimal temperature of in vitro growth of the isolate IFB0099 was in the range of 33 to $35{ }^{\circ} \mathrm{C}$, a temperature of $26{ }^{\circ} \mathrm{C}$ was applied in the present study to test the resistance of potato tubers to $D$. solani bacteria, because it is favourable for both successful infection and rot development and allows the selection of potato genotypes with higher levels of resistance.

\section{Tuber Resistance to D. solani of Potato Diploid Clones and Cultivars}

There were differences in DI among the tested diploid hybrids of Solanum at a temperature of $26{ }^{\circ} \mathrm{C}$. The mean DI in the tested diploids was 0.53 and ranged from 0 to 0.97 (Table 1). The diploid clone DG 88-9 did not show any symptoms of infection $(0 / 30$ tubers $)$. In contrast, in the susceptible standard cv. Irys and the medium-resistant cv. Glada, all tested tubers (60/60 tubers) and 58/60 tubers were infected, respectively (Table 1). This was the reason to express the resistance to soft rot using two parameters, DS and DI, separately. To express overall reaction of tested clones, the SR parameter was calculated. Mostly, genotypes with low DS were characterised by low DI, but there were some exceptions: clone DG 06-1 showed DS equal to $2.8 \mathrm{~g}$, but only two tubers out of 30 were infected.
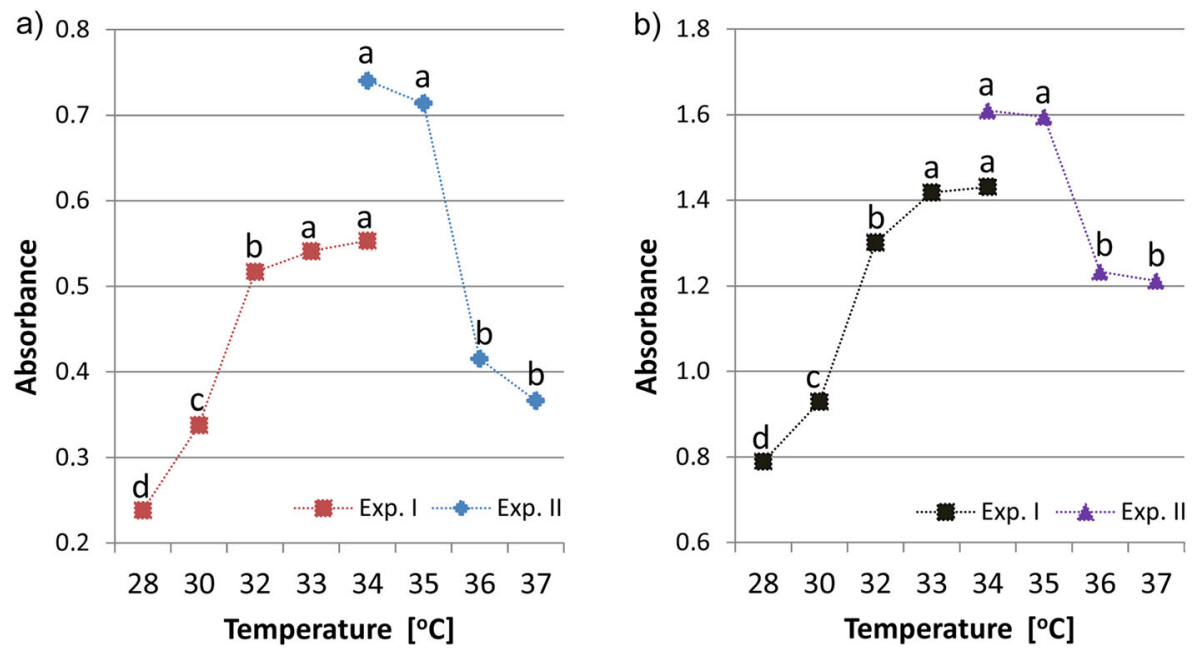

Fig. 3 Turbidity at a wavelength of $600 \mathrm{~nm}$ of Dickeya solani strain IFB0099 ${ }^{a}$ with shaking at various temperatures in Luria Bertani medium: $\mathbf{a}$ after $6 \mathrm{~h}$, b after $8.5 \mathrm{~h}$ of incubation. Means for each of the experiments followed by the same letter do not differ significantly according to Duncan's test at $P=0.05$ 
Two-way ANOVA of the average weight of rot (SR) and disease severity (DS) indicated significant effects of potato genotype on tested traits. The effects of the three test dates (including two growing seasons) and genotype $\times$ date interaction were not significant. The mean values of SR, DS and DI for diploids and potato cultivars are presented in Table 1. The symptoms of infection are shown in Fig. 1. Twenty-four diploids did not differ significantly for SR from the somatic hybrid of S. tuberosum and S. brevidens, USA 249, which is widely known for its high resistance to soft rot (Austin et al. 1988). In the tested diploid clones (with the exception of DG 08-305, which was identified as susceptible to $P$. atrosepticum tuber infection in previous studies; Online Resource 2), the mean DS was $1.13 \mathrm{~g}$ with a range from 0.4 to $2.4 \mathrm{~g}$. This was less than the moderately resistant control cultivar Glada (4.69), the susceptible control cultivar Irys (12.97) and diploid DG 08-305 (4.81).

The group of diploid interspecific hybrids of Solanum selected out of 394 diploid clones based on high resistance to P. atrosepticum (Lebecka et al. 2013; Online Resource 1) was characterised in the present study as having a significantly higher level of tuber resistance than potato cultivars to the aggressive strain of $D$. solani. Strain IFB0099, with high aggressiveness towards potato (Golanowska et al. 2015), was applied for laboratory screening of tuber resistance to soft rot. The resistance level of tested diploids to $P$. atrosepticum and $D$. solani could not be compared directly because of different testing procedures and scoring methods, but the selected diploids were equal or significantly better in resistance than the most resistant potato cultivar Glada. Clone DG 08-305 susceptible to $P$. atrosepticum, deliberately chosen for its susceptibility, was also susceptible to the $D$. solani strain.

\section{Plant Resistance of Potato Diploid Clones and Potato Cultivars to D. solani}

ANOVA revealed significant differences between the genotypes (clones/cultivars) but not between the test dates for the number of plants with symptoms of infection by D. solani. There was no significant genotype $\times$ test date interaction. The percentage of symptomatic plants ranged from 0 to $53.5 \%$ in the tested diploids. Seventeen clones showed significantly lower percentages of infection by $D$. solani than the most resistant potato cultivar Glada, after inoculation of the stem base of plants (Table 1).

\section{Fertility of Diploid Hybrids}

Interspecific diploid hybrids of Solanum were obtained after several back-crosses of wild species to dihaploids of Solanum tuberosum and recurrent selection. These hybrids originated from $S$. tuberosum and wild/primitive cultivated species of Solanum, such as S. acaule, S. andigena, S. chacoense, S. demissum, S. goniocalyx, S. gourlayi, S. microdontum, S. phureja, S. stenotomum, S. stoloniferum, S. verrucosum and S. yungasense. Pollen is considered fertile when at least $30 \%$ is stained (Janssen and Hermsen 1976). The tested diploids possessed 30 to $90 \%$ (mean 65\%) stained pollen, and 11 diploids produced unreduced gametes (inferred from large pollen grains), and a few clones were characterised by low pollen production. The results are presented in Table 1 . The ability to produce $2 n$ gametes is crucial for potato germplasm enhancement (Watanabe 2015). The diploid clones with such ability are suitable for direct use in crosses with $4 x$ potato breeding lines to improve the resistance of potato to 
pectinolytic bacteria. The predominant involvement of significant additive effects in the inheritance of resistance to soft rot of tubers allows selection of parental forms for crossing on the basis of their phenotype when they are evaluated for a few seasons (Lebecka and Zimnoch-Guzowska 2004). A high level of resistance to P. atrosepticum was successfully transferred from selected diploid hybrids of Solanum spp. to tetraploid potato by using $4 x$ - $2 x$ crosses (Lebecka et al. 2004). The first potato cultivar originating from the selected diploid clone DG 88-9, Mieszko, was characterised as the most resistant to tuber rot after wound inoculation with $D$. solani in a group of 11 potato cultivars (Lebecka and Michalak 2017).

The results obtained in the present study show that selected diploid interspecific clones of Solanum spp. can be used directly in potato breeding programmes to improve the level of resistance to potato soft rot and blackleg caused not only by bacteria of the genus Pectobacterium but also by bacteria of the genus Dickeya. These wellcharacterised clones are currently being used in research to examine this complex polygenic trait at both the genetic and proteomic levels (Lebecka et al. 2019).

Open Access This article is licensed under a Creative Commons Attribution 4.0 International License, which permits use, sharing, adaptation, distribution and reproduction in any medium or format, as long as you give appropriate credit to the original author(s) and the source, provide a link to the Creative Commons licence, and indicate if changes were made. The images or other third party material in this article are included in the article's Creative Commons licence, unless indicated otherwise in a credit line to the material. If material is not included in the article's Creative Commons licence and your intended use is not permitted by statutory regulation or exceeds the permitted use, you will need to obtain permission directly from the copyright holder. To view a copy of this licence, visit http://creativecommons.org/licenses/by/4.0/.

\section{References}

Austin S, Lojkowska E, Ehlenfeldt MK, Kelman A, Helgeson JP (1988) Fertile interspecific somatic hybrids of Solanum: a novel source of resistance to Erwinia soft rot. Phytopathol 78:1216-1220

Czajkowski R, de Boer WJ, van der Zouwen PS, Kastelein P, Jafra S, de Haan EG, van den Bovenkamp GW, van der Wolf JM (2013) Virulence of 'Dickeya solani' and Dickeya dianthicola biovar-1 and -7 strains on potato (Solanum tuberosum). Plant Pathol 62:597-610

Dees MW, Lebecka R, Perminow JIS, Czajkowski R, Grupa A, Motyka A, Zoledowska S, Śliwka J, Lojkowska E, Brurberg MB (2017) Characterization of Dickeya and Pectobacterium strains obtained from diseased potato plants in different climatic conditions of Norway and Poland. Eur J Plant Pathol 148: 839-851

du Raan S, Coutinho TA, van der Waals JE (2016) Cardinal temperature differences, determined in vitro, between closely related species and subspecies of pectinolytic bacteria responsible for blackleg and soft rot on potatoes. Eur J Plant Pathol 144:361-369

Golanowska M, Galardini M, Bazzicalupo M, Hugouvieux-Cotte-Pattat N, Mengoni A, Potrykus M, Slawiak M, Lojkowska E (2015) Draft genome sequence of a highly virulent strain of the plant pathogen Dickeya solani, IFB0099. Genome Announc 3(2):e00109-e00115. https://doi.org/10.1128/genomeA.00109-15

Golanowska M, Potrykus M, Motyka-Pomagruk A, Kabza M, Bacci G, Galardini M, Bazzicalupo M, Makalowska I, Smalla K, Mengoni A, Hugouvieux-Cotte-Pattat N, Lojkowska E (2018) Comparison of highly and weakly virulent Dickeya solani strains, with a view on the pangenome and panregulon of this species. Front Microbiol 9:1940

Janssen AWB, Hermsen JGT (1976) Estimating pollen fertility in Solanum species and haploids. Euphytica 25:577-586

Kraepiel Y, Barny M (2016) Gram-negative phytopathogenic bacteria, all hemibiotrophs after all? Mol Plant Pathol 17:313-316 
Latour X, Diallo S, Chevalier S, Morin D, Smadja B, Burini JF, Haras D, Orange N (2007) Thermoregulation of $\mathrm{N}$-acyl homoserine lactone-based quorum sensing in the soft rot bacterium Pectobacterium atrosepticum. Appl Environ Microbiol 73:4078-4081

Lebecka R (2017) Screening for potato resistance to blackleg and soft rot. Plant Breed Seed Sci 75:97-104

Lebecka R, Czarniak Z (2019) Laboratory evaluation of infection symptoms caused by highly aggressive strains of bacteria: Dickeya solani and Pectobacterium carotovorum subsp. brasiliense in potato tubers (in Polish). Ziemniak Pol 1:22-27

Lebecka R, Michalak K (2017) Tubers reaction of selected potato cultivars to infection with highly virulent strain of bacteria Dickeya solani (in Polish). Ziemniak Pol 3:18-23

Lebecka R, Zimnoch-Guzowska E (2004) The inheritance of resistance to soft rot (Erwinia carotovora subsp atroseptica) in diploid potato families. Am J Potato Res 81:395-401

Lebecka R, Zimnoch-Guzowska E, Kaczmarek Z (2004) Resistance to soft rot (Erwinia carotovora subsp atroseptica) in tetraploid potato families obtained from $4 x-2 x$ crosses. Am J Potato Res 82:203-210

Lebecka R, Jakuczun H, Wasilewicz-Flis I, Zimnoch-Guzowska E (2013) Ziemniaki diploidalne źródłem wysokiej odporności na bakterie Pectobacterium atrosepticum. Prog Plant Prot/Post Ochr Rośl 53:413417 https://doi.org/10.14199/ppp-2013-106

Lebecka R, Flis B, Murawska Z (2018) Comparison of temperature effects on the in vitro growth and disease development in potato tubers inoculated with bacteria Pectobacterium atrosepticum, P. carotovorum subsp carotovorum and Dickeya solani. J Phytopathol 166:654-662

Lebecka R, Kistowski M, Dębski J, Szajko K, Murawska Z, Marczewski W (2019) Quantitative proteomic analysis of differentially expressed proteins in tubers of potato plants differing in resistance to Dickeya solani. Plant Soil 441:317-329

Pérombelon MCM (2002) Potato diseases caused by soft rot erwinias: an overview of pathogenesis. Plant Pathol 51:1-12

Pérombelon MCM, Kelman A (1980) Ecology of the soft rot erwinias. Annu Rev Phytopathol 18:361-387

Portier P, Pédron J, Taghouti G, Fischer-Le Saux M, Caullireau E, Bertrand C et al (2019) Elevation of Pectobacterium carotovorum subsp. odoriferum to species level as Pectobacterium odoriferum sp. nov., proposal of Pectobacterium brasiliense sp. nov. and Pectobacterium actinidiae sp. nov., emended description of Pectobacterium carotovorum and description of Pectobacterium versatile sp. nov., isolated from streams and symptoms on diverse plants. Int J Syst Evol Microbiol 69:3207-3216

Sławiak M, Łojkowska E, van der Wolf JM (2009) First report of bacterial soft rot on potato caused by Dickeya sp. (syn. Erwinia chrysanthemi) in Poland. Plant Pathol 58:794

Toth IK, Birch PRJ (2005) Rotting softly and stealthily. Curr Opin Plant Biol 8:424-429

Toth IK, Bell KS, Holeva MC, Birch PR (2003) Soft rot erwiniae: from genes to genomes. Mol Plant Pathol 4: $17-30$

Toth IK, van der Wolf JM, Saddler G, Łojkowska E, Hélias V, Pirhonen M, Tsror (Lahkim) L, Elphinstone JG (2011) Dickeya species: an emerging problem for potato production in Europe. Plant Pathol 60:385-399

Tsror (L)L, Erlich O, Lebiush S, Hazanovsky M, Zig U, Sławiak M, Grabe G, van der Wolf JM, van de Haar JJ (2009) Assessment of recent outbreaks of Dickeya sp. (syn. Erwinia chrysanthemi) slow wilt in potato crops in Israel. Eur J Plant Pathol 123:311-320

Wasilewicz-Flis I (2011) Oceny cytologiczne stosowanych w pracach hodowlano-genetycznych nad ziemniakiem (in Polish). Ziemniak Pol 1:1-5

Watanabe K (2015) Potato genetics, genomics and applications. Breed Sci 65:53-68

van der Wolf JM, de Haan EG, Kastelein P, Krijger M, de Haas BH, Velvis H, Mendes O, Kooman-Gersmann M, van der Zouwen PS (2017) Virulence of Pectobacterium carotovorum subsp. brasiliense on potato compared with that of other Pectobacterium and Dickeya species under climatic conditions prevailing in the Netherlands. Plant Pathol 66:571-583

Zimnoch-Guzowska E, Lebecka R, Pietrak J (1999) Soft rot and blackleg reactions in diploid potato hybrids inoculated with Erwinia spp. Am J Potato Res 76:199-207

Zimnoch-Guzowska E, Marczewski W, Lebecka R, Flis B, Schäfer-Pregl R, Salamini F, Gebhardt C (2000) QTL analysis of new sources of resistance to Erwinia carotovora ssp. atroseptica in potato done by AFLP, RLFP, and resistance-gene-like markers. Crop Sci 40:1156-1167

Publisher's Note Springer Nature remains neutral with regard to jurisdictional claims in published maps and institutional affiliations. 